\title{
PENURUNAN KOGNITIF PADA PEKERJA DENGAN TULI SENSORINEURAL AKIBAT BISING
}

\author{
Yudhiakuari Sincihu* ${ }^{\star 凶}$, Melany Taurusia*
}

\begin{abstract}
Abstrak
Kemampuan kognitif sangat diperlukan pekerja dalam menjalankan aktivitas pekerjaannya sehingga produktifitas dapat maksimal. Perusahaan galangan kapal selalu menghasilkan bising sebagai risiko bahaya kesehatan bagi pekerjanya. Pemeriksaan audiometri tahun 2018 menemukan 81,2\% dengan kelainan tuli sensorineural akibat bising pada pekerja galangan kapal. Penelitian ini bertujuan untuk menganalisis hubungan ketulian sensorineural akibat bising dengan kemampuan kognitif (seperti fungsi visiokontruksi, penamaan, memori, atensi, berbahasa, berpikir abstrak, memori tertunda, dan orientasi). Penelitian ini adalah penelitian observasional dengan pendekatan cross-sectional. Lokasi penelitian di perusahaan galangan kapal di Surabaya. Populasi adalah pekerja bagian produksi galangan kapal, sebanyak 314 orang, dan ditemukan 49 subjek sebagai sampel yang memenuhi kriteria inklusi dan eksklusi. Data fungsi kognitif diambil menggunakan kuesioner Moca-Ina. Hasil penelitian menunjukan 79,6\% subjek mengalami gangguan fungsi kognitif, $57,1 \%$ tuli derajat ringan, $16,3 \%$ tuli derajat sedang, 2,1\% tuli derajat sedang-berat, dan 2,1\% tuli derajat berat. Analisis statistik non-parametrik dengan uji Spearman antara derajat ketulian dengan skor kognitif subjek penelitian menunjukan hubungan yang rendah namun bermakna $(r=0,306, p=0,032)$. Kesimpulan penelitian ini adalah semakin berat derajat ketulian yang diderita pekerja berhubungan dengan semakin rendahnya kemampuan kognitif mereka.
\end{abstract}

Kata kunci: bising, gangguan kognitif, tuli sensorineural.

\section{COGNITIVE IMPAIRMENT IN WORKERS WITH SENSORINEURAL HEARING LOSS DUE TO NOISE}

\begin{abstract}
Cognitive ability is needed by employees in carrying out their work activities so that productivity can be maximized. Shipyard companies always produce noise as a risk to health hazards for their workers. Audiometry examination in 2018 was found $81.2 \%$ with sensorineural hearing loss due to noise in shipyard employees. This study aims to analyze the relationship between the sensorineural hearing loss due to noise and cognitive abilities (such as visioconstruction function, naming, memory, attention, language, abstraction, delayed recall, and orientation). This was an observational study with a cross-sectional approach. Research location was in a shipyard companyin Surabaya. The population was shipyard production employees, as many as 314 people, then 49 subjects were found as samples that met the inclusion and exclusion criteria. Cognitive function data were taken using the Moca-Ina questionnaire. The results showed $79.6 \%$ of subjects with cognitive problem, $57.1 \%$ mild degree deafness, $16.3 \%$ moderate deafness, $2.1 \%$ moderate to severe deafness, and $2.1 \%$ severe deafness. Non-parametric statistical analysis by Spearman test between degrees of deafness and cognitive scores of research subjects showed a low but significant relationship ( $r=0.306, p$ $=0.032$ ). The conclusion of this study is that the heavier the level of deafness suffered by employees is related to a decrease in their cognitive abilities.
\end{abstract}

Keywords: cognitive disorder, noise, sensorineural deafness.

* Departemen IImu Kesehatan Masyarakat, Fakultas Kedokteran, Universitas Katolik Widya Mandala Surabaya.

E-mail: yudhiakuari@ukwms.ac.id 


\section{Pendahuluan}

Bising mempunyai dampak auditori dan non-auditori. ${ }^{1}$ Non-audiotori berupa stres, kelelahan, gangguan komunikasi, perasaan mudah marah, percepatan denyut nadi, peningkatan tekanan darah, dapat menurunkan gairah kerja yang akan menyebabkan peningkatan absensi. ${ }^{1,2,3}$ Sampai saat ini belum ada penjelasan ilmiah terkait dampak bising terhadap fungsi kognitif.

Perusahaan galangan kapal Surabaya adalah perusahaan yang bergerak dibidang pembuatan dan perbaikan kapal. Setiap industry yang melakukan proses produksi akan menghasilkan bising dari proses kerja dan berbagai mesin yang digunakan. ${ }^{4}$ Batas ambang bising yang diajurkan adalah $\leq 85 \mathrm{dBA}$ selama 8 jam kerja. 4,5,6 Penelitian Alwi menyebutkan bahwa industri galangan kapal mempunyai risiko dengan kategori tinggi, salah satunya adalah bising. ${ }^{7}$ Bising sebagai penyebab menurunnya pendengaran tipe sensorineural (Sensorineural Hearing Loss). Diagnosis gangguan pendengaran akibat bising yang terus menerus diatas ambang batas disebut Noise Induced Hearing Loss $(\mathrm{NIHL}){ }^{8}$

Berdasarkan data skrining audiometri tahun 2018 pada pekerja unit produksi galangan kapal Surabaya, ditemukan $81,2 \%$ dengan ketulian SNHL. Temuan ini lebih tinggi dibandingkan penelitian Alexopoulos di galangan kapal India pada tahun 2015 yang menyebutkan bahwa prevalensi NIHL sebesar $27,1 \% .{ }^{9}$ Menurut WHO, prevalensi ketulian di Indonesia sebesar $4,2 \%$ dengan $\mathrm{NIHL}$ sebagai diagnosis terbanyak. ${ }^{10}$

Peneliti menduga ada keterkaitan antara pekerja yang mengalami tuli sensorineural dengan kemampuan kognitif mereka dalam bekerja. Penelitian yang menunjang pernah dilaporkan oleh Park tahun 2018 pada hewan tikus, yaitu adanya penurunan fungsi kognitif tikus jika mengalami ketulian. ${ }^{11}$
Kemampuan kognitif pekerja sangat menentukan kinerja mereka. Kinerja diartikan sebagai sejauh mana seseorang dapat melaksanakan tanggung jawab dan tugas kerja yang diberikan. ${ }^{12,13}$ Untuk itu pekerja memerlukan fungsi visiokontruksi, atensi, kalkulasi, orientasi, kemampuan berbahasa dan memori yang tergolong baik dalam fungsi kognitif pada alat ukur MoCa-Ina. ${ }^{14}$

Penelitian ini bertujuan untuk menganalisis korelasi antara tuli sensorineural akibat bising kerja dengan kemampuan kognitif.

\section{Bahan dan Metode}

\section{Desain Penelitian}

Penelitian ini adalah penelitian observasional analitik korelasional dengan pendekatan cross sectional. Penelitian ini telah mendapat sertifikat laik etik dengan Nomor. 0756/WM12/Q/2018 oleh Komite Etik Fakultas Kedokteran Universitas Katolik Widya Mandala Surabaya.

\section{Populasi dan Sampel Penelitian}

Populasi penelitian ini adalah semua pekerja bagian produksi (unit kerja lambung kapal, bengkel mesin, limbung, kontruksi, perlengkapan, ruang kompresor, dan bengkel listrik) sebuah perusahan galangan kapal di Surabaya. Jumlah populasi diketahui 314 orang. Sampel diambil dengan metode purposive sampling. Didapatkan sampel sebanyak 49 orang yang memenuhi kriteria inklusi dan ekslusi penelitian. Kriteria inklusi adalah bersedia menjadi subjek penelitian dengan mengisi informed consent setelah mendapat penjelasan lengkap. Kriteria ekslusi adalah depresi, skizofrenia, parkinson, buta aksara, kelumpuhan anggota gerak, diabetes mellitus, hipertensi, kelainan anatomi telinga, corpus alineum, riwayat cidera kepala, dan riwayat trauma organ pendengaran. 
Penelitian ini dikerjakan selama 6 bulan, yaitu bulan Mei - September 2018.

\section{Variabel Penelitian}

Variabel independen yaitu derajat tuli sensorineural. Variabel dependen adalah kemampuan kognitif.

\section{Definisi Operasional}

Tuli sensorineural atau Sensorineural Hearing Loss (SNHL) adalah gangguan pendengaran pada subjek yang disebabkan kerusakan saraf pendengaran akibat bising kerja, didiagnosis berdasarkan pemeriksaan audiometri dan diinterprestasi oleh Dokter Spesialis Telinga Hidung Tenggorokan. Fungsi kognitif adalah kemampuan visiokonstruksi, penamaan, memori, perhatian, berbahasa, berpikir abstrak, memori tertunda, dan orientasi yang dimiliki subjek; diukur menggunakan kuesioner Moca-Ina.

\section{Teknik Pengumpulan Data}

SNHL dan fungsi kognitif adalah data primer. Subjek melakukan pemeriksaan audiometri dan diwawancarai menggunakan panduan kuesioner Moca-Ina secara tertutup.
Subjek dipastikan mampu mendengar instruksi dan telah mengerti terhadap pertanyaan selama pengisian kuesioner berlangsung. Kuesioner telah divalidasi sebelumnya.

\section{Teknik Analisis Data}

Karakteristik subjek seperti usia, tingkat pendidikan, unit kerja, lama kerja, kebiasaan mengkonsumsi alkohol, kebiasaan merokok, dan indeks massa tubuh disajikan dalam bentuk tabel distribusi. Analisis korelasional dilakukan dengan uji Spearman karena merupakan data non-parametrik berskala ordinal pada variabel independennya dan berskala data rasio pada variabel dependen. Disebut signifikan jika ditemukan hasil $p$ value $<0,05$.

\section{Hasil}

\section{Subjek Penelitian}

Dipilih 49 subjek yang sesuai dengan kriteria. Tidak ditemukan subjek dengan riwayat penggunaan obat psikotropika maupun obat-obatan ototoksik dari data rekam medis pekerja di Poliklinik perusahaan. Deskripsi lainnya ditunjukkan pada Tabel 1.

Tabel 1. Deskripsi subjek penelitian.

\begin{tabular}{lcc}
\hline \multicolumn{1}{c}{ Variabel } & Jumlah Subjek & Persentase (\%) \\
\hline Usia Subjek & 2 & \\
<40 tahun & $2 / 49$ \\
41-45 tahun & 7 & $7 / 49$ \\
46-50 tahun & 36 & $36 / 49$ \\
51-55 tahun & 4 & $4 / 49$ \\
Tingkat Pendidikan & & \\
$\quad$ Lulus SMP & 1 & $1 / 49$ \\
$\quad$ Lulus SMU/Sederajat & 46 & $46 / 49$ \\
$\quad$ Lulus Sarjana (S1) & 2 & $2 / 49$ \\
Kebiasan Merokok & & \\
Ya & 24 & $24 / 49$ \\
Tidak & 25 & $25 / 49$ \\
Indeks Massa Tubuh (IMT) & & $1 / 49$ \\
IMT kurang & 1 & $26 / 49$ \\
IMT Normal & 26 & $11 / 49$ \\
Kegemukan & 11 & $11 / 49$ \\
Obesitas & 11 & \\
\hline
\end{tabular}


Berdasarkan Tabel 1, dapat dijelaskan bahwa sebagian besar $(73,5 \%)$ subjek penelitian berusia 46-50 tahun, yaitu usia sebelum masa pensiun bagi pekerja. Jika dirinci lebih lanjut, sebesar $79,6 \%$ telah bekerja $\geq 20$ tahun. Gambaran tempat kerja subjek peneltiian adalah 12/49 subjek bekerja dibagian kontruksi, 8/49 dibagian mesin, 8/49 di bagian kelistrikan, 8/49 di bagian sarana dan fasilitas, 7/49 dibagian perlenkapan, 4/49 diarea lambung kapal, dan 2/49 sebagai pimpinan produksi. Tingkat pendidikan subjek terbanyak adalah lulusan SMU/Sederajat (93,9\%). Ditemukan 48,9\% subjek mempunyai kebiasaan merokok, $34,7 \%$ diantaranya merokok $\geq 1$ bungkus per hari. Sebagian besar $(53,1 \%)$ subjek mempunyai berat badan ideal, tetapi juga terdapat subjek dengan kegemukan $(22,4 \%)$ dan obesitas (22,4\%).

\section{Ketulian pada Subjek Penelitian}

Pemeriksaan audiometri menunjukan 38/49 subjek penelitian dengan tuli sensorineural (Gambar 1). Jika dirinci lebih lanjut, maka diketahui bahwa sebanyak 14/38 subjek mengalami gangguan tuli hanya pada salah satu telinga saja (kanan/kiri), sedangkan sisanya, sebanyak 24/38 mengalami gangguan pada kedua telinga. Derajat keparahan tuli sensorineural yang dialami subjek dapat dilihat pada Gambar 2, didapatkan bahwa paling banyak (28/38) subjek menderita tuli sensorineural derajat ringan. Ditemukan juga $8 / 38$ tuli derajat sedang, $1 / 38$ tuli derajat sedangberat, dan $1 / 38$ tuli derajat berat.

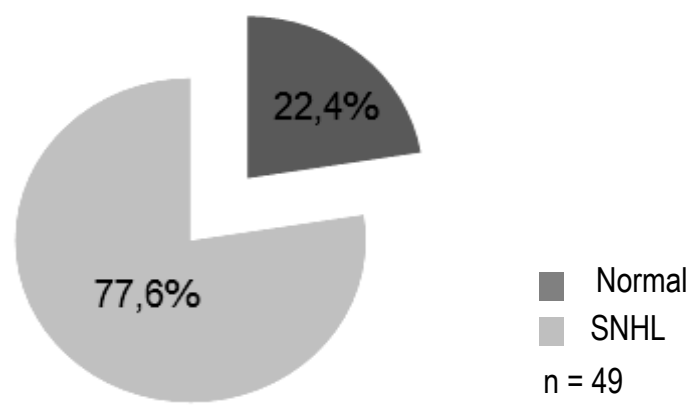

Gambar 1. Prevalensi tuli sensorineural (SNHL) pada subjek penelitian

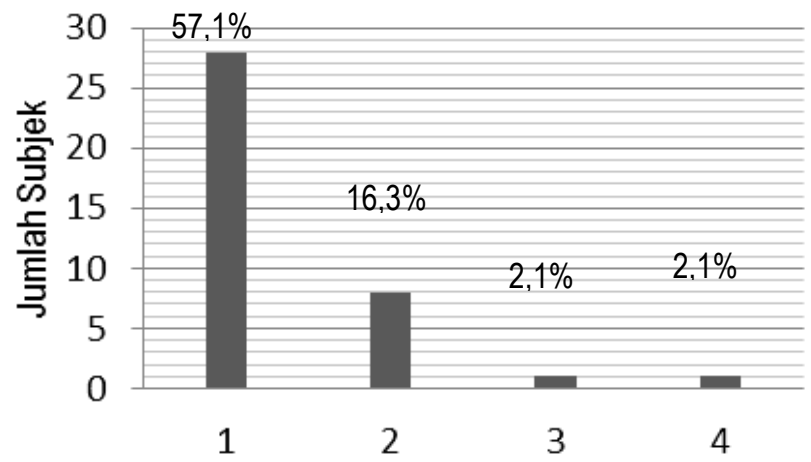

Gambar 2. Prevalensi tuli sensorineural (SNHL) berdasarkan derajat keparahannya. Keterangan: (1) SNHL derajat ringan, (2) SNHL derajat sedang, (3) SNHL derajat sedang-berat, (4) SNHL derajat berat. 
Kemampuan Kognitif Subjek Penelitian

Hasil penilaian kemampuan kognitif subjek penelitian menggunakan kuesioner MoCa-Ina didapatkan 39/49 dengan gangguan kognitif (skor MoCa-Ina <26). Hanya terdapat 10/49 subjek dalam batas kognitif normal. Rerata skor kognitif adalah 21,53, median 22 , dan standar deviasi sebesar 4,184. Detail tiap fungsi kognitif yang mengalami gangguan pada subjek penelitian dijelaskan lebih lanjut pada Gambar 4, bahwa gangguan kognitif pada subjek penelitian paling banyak terjadi pada fungsi visiokonstruksi (47/49), dan fungsi memori (38/49). Kedua fungsi ini sangat penting sebagai pekerja yang memproduksi kapal. Seterusnya, 33/49 mengalami gangguan fungsi berbahasa, 33/49 subjek mengalami gangguan atensi, $32 / 49$ mengalami gangguan fungsi berpikir abstrak, dan 15/49 mengalami gangguan orientasi. Namun, fungsi penamaan masih cenderung baik, hanya 6/49 subjek dengan gangguan.

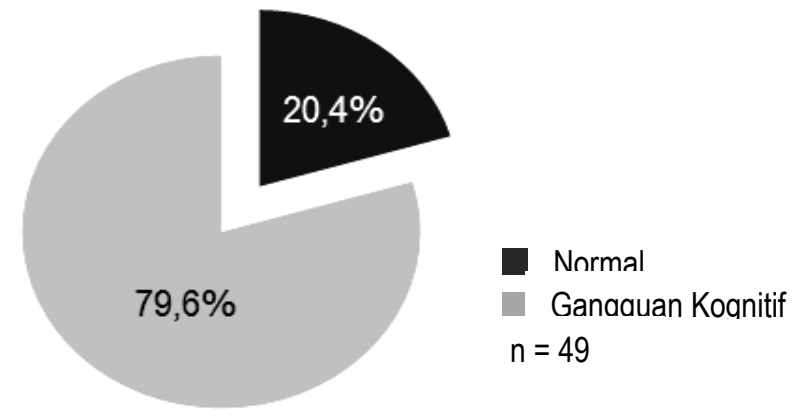

Gambar 3. Deskripsikemampuan kognitif pada subjek penelitian.

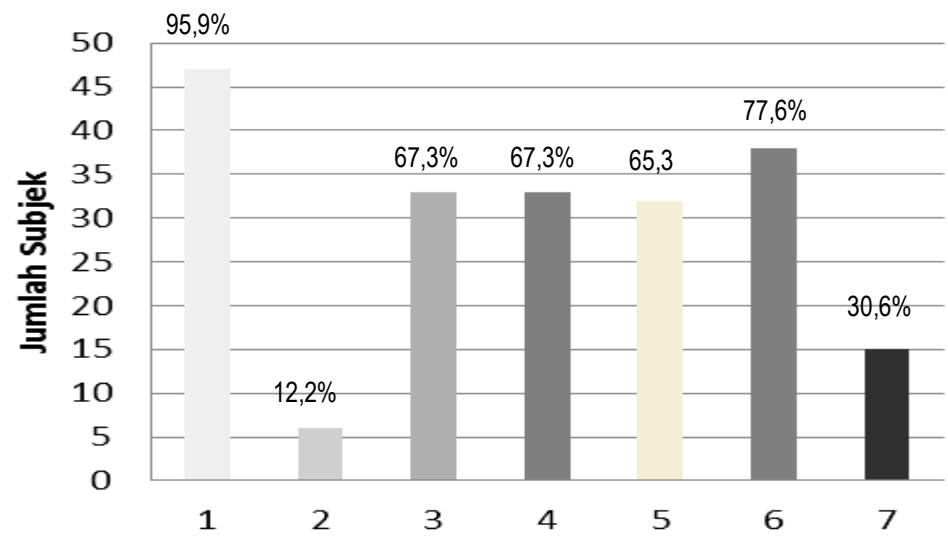

Gambar 4. Persentase gangguan tiap fungsi kognitif.

Keterangan: (1) Fungsi Visiokonstruksi, (2) Fungsi penamaan, (3) Fungsi atensi, (4) Fungsi berbahasa, (5) Fungsi berpikir abstrak, (6) Fungsi memori, (7) Fungsi orientasi. 


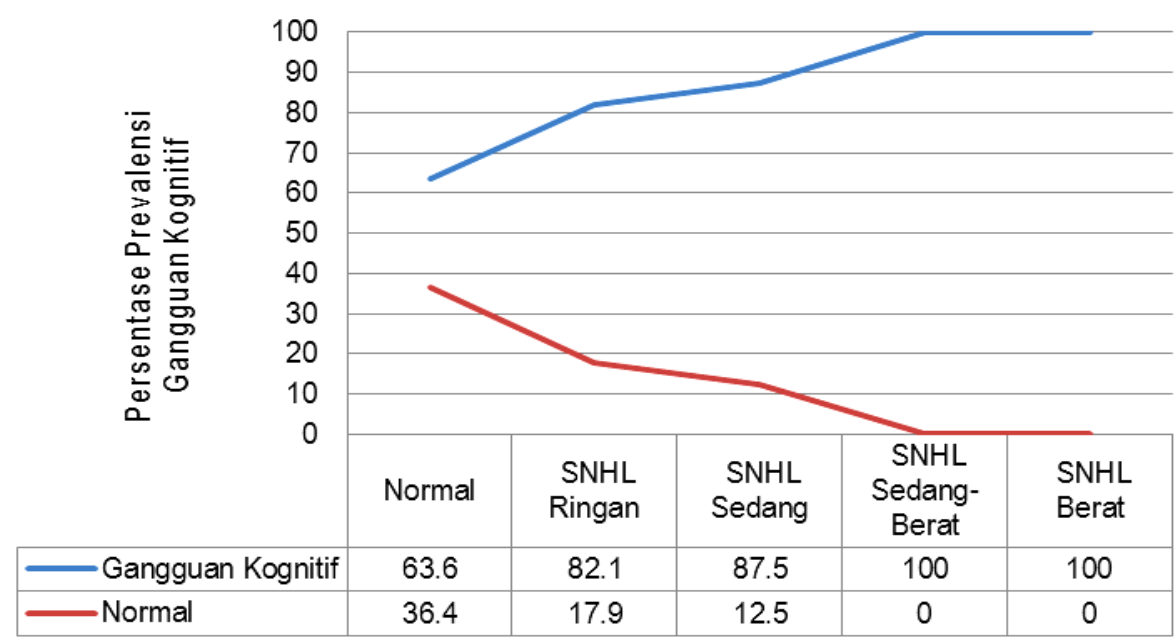

Gambar 5. Korelasi derajat keparahan tuli sensorineural (SNHL) dengan prevalensi gangguan kognitif pada subjek penelitian.

\section{Korelasi Bivariat}

Hasil analisis statistik menggunakan Spearman korelasi menunjukan nilai $p=$ 0,032 , dengan koefisien korelasi ( $r$ ) sebesar 0,306 . Nilai $p<0.05$ berarti ada korelasi (meskipun rendah) antara derajat keparahan tuli sensorineural dengan kejadian gangguan kognitif pada subjek. Gambar 5 menjelaskan bahwa semakin berat derajat ketulian yang dialami subjek berhubungan dengan bertambah buruknya fungsi kognitif mereka, demikian pula sebaliknya. Namun demikian, pada penelitian ini juga ditemukan subjek tanpa gangguan pendengaran yang mengelami gangguan kognitif, yakni sebesar $63,6 \%$.

\section{Pembahasan}

Jenis pekerjaan di perusahaan galangan kapal adalah kerja kasar dan lebih dominan menggunakan kekuatan otot. $\mathrm{Hal}$ ini menjelaskan deskripsi dominasi pekerja dengan tingkat pendidikan lulus SMP dan SMU, maupun banyaknya pekerja dengan kebiasaan merokok. Deskripsi subjek penelitian yang serupa juga dilaporkan oleh Harianto (2013), Kuemba (2012), dan Jumali (2013) pada penelitian yang dilakukan dengan subjek pekerja kasar. ${ }^{15,16,17}$ Akan tetapi deskripsi usia tidak seperti pada penelitian Harianto dan Kuemba namun sejalan dengan penelitian Jumali. Hal ini dikarenakan kebijakan perusahaan yang tetap mempekerjakan mereka sampai dengan usia pensiun 55 tahun. Kebijakan ini ditetapkan berkaitan dengan jenis pekerjaan yang dilakukan di perusahaan ini adalah pekerjaan ahli yang harus mendapat pelatihan sebelumnya, karena akan berisiko besar jika terjadi kesalahan produksi. Jenis pekerjaan ini juga yang melandasi temuan indeks massa tubuh yang didominasi ideal, dan hanya satu dari lima subjek terkategori overweight maupun obesitas. Harianto juga menjelaskan perihal yang serupa pada temuannya. ${ }^{15}$

Tiga dari empat subjek penelitian mengalami tuli sensorineural (SNHL) yang ditemukan dari pemeriksaan audiometri. Audiometri adalah standar baku dalam menentukan jenis ketulian. ${ }^{1}$ Tuli akibat bising merupakan jenis ketulian sensorineural.1,18 Peneliti telah memastikan adanya sumber bising diatas ambang batas seperti aktivitas pemotongan besi (cutting), pemukulan palu pada plat kapal (chipping), penyambungan plat besi rangka kapal (welding), pembersihan 
kapal (sandblasting), pemasangan paku plat (riveting), suara generator, kompresor, blower, mesin ringlet, dan gerinda. Menurut Rambe ${ }^{18}$, ketulian akibat bising timbul secara bertahap dalam jangka waktu 8-10 tahun pertama paparan. Hasil penelitian ini menunjukan tiga dari empat orang subjek penelitian telah bekerja $\geq 20$ tahun. Selain itu, peneliti telah mengekslusi semua faktor risiko lain penyebab ketulian, sehingga dapat dikatakan gangguan tuli pada subjek adalah akibat bising kerja diatas ambang batas yang terjadi secara terus menerus (Noise Induced Hearing Loss).

Derajat ketulian yang paling banyak ditemukan adalah SNHL derajat ringan, kemudian SNHL derajat sedang. Akan tetapi juga ditemukan 1 kasus SNHL derajat sedang-berat serta 1 kasus SNHL derajat berat pada subjek. Hal ini dapat dijelaskan dari waktu kerja produksi pekerja galangan kapal yakni selama 8 jam setiap harinya dengan banyak sumber bising diatas ambang batas anjuran serta lama kerja yang diatas 20 tahun. 6,18

Ditemukan empat dari lima orang subjek penelitian dengan gangguan kemampuan kognitif. Faktor jenis pekerjaan yang didominasi fisik, dan kebiasaan merokok berpengaruh terhadap prevalensi gangguan kognitif mereka. Seperti penjelasan Sabia dalam penelitiannya pada subjek perokok ${ }^{19}$, dan penelitian Psaltopoulou yang menjelaskan keterkaitan antara riwayat aktivitas fisik terhadap ketergantungan kognitif pada Lansia di Yunani. ${ }^{20}$ Kondisi ini juga terlihat pada Gambar 5 yang menunjukkan korelasi antara derajat keparahan tuli sensorineural dengan prevalensi gangguan kognitif sebesar $63,6 \%$ subjek mengalami gangguan kemampuan kognitif walaupun fungsi pendengarannya dalam batas normal. Menurut Mani, terdapat faktor lain yang belum dianalisis, seperti keadaan stres pada pekerja dan kondisi keuangan mereka. ${ }^{21}$ Faktor lainnya belum dianalisis, tetapi peneliti memberikan asumsi bahwa bising saja dapat menimbulkan gangguan kemampuan kognitif sebelum timbulnya gangguan pendengaran. Hal ini masih perlu dibuktikan lebih lanjut.

Berdasarkan domain kognitifnya, hampir semua subjek penelitian mengalami gangguan fungsi visiokonstruksi/eksekutif, dan ditemukan tiga dari empat subjek terganggu fungsi memorinya. Kedua fungsi ini sangat penting perannya dalam proses menerima, mengolah, menyimpan, dan mempergunakan suatu informasi dalam setiap pekerjaan mereka. Diamond menjelaskan bahwa buruknya fungsi eksekutif individu dikaitkan dengan rendahnya produktivitas. Dilain pihak, pekerja dengan fungsi eksekutif yang buruk akan kesulitan mempertahankan hubungan antar sesama dan cenderung bertindak impulsif. ${ }^{22}$

Temuan ini tidak sependapat dengan pimpinan produksi di perusahaan tersebut, yaitu diinformasikan bahwa:

"para karyawan tidak pernah ada kendala dalam menyelesaikan pekerjaan seharihari mereka, walaupun mereka sedikit temperamental, hal ini karena lingkungan kerja yang bising dan keras".

Kontradiksi temuan ini mungkin saja disebabkan kebiasaan kerja yang telah dilakukan selama bertahun-tahun oleh mereka, sehingga pekerja menjadi terbiasa dengan pekerjaannya. Akan tetapi, timbul suatu masalah jika mengerjakan perihal diluar pekerjaannya saat ini, misalnya dipindah ke jenis pekerjaan lainnya. Dari pengamatan peneliti, juga diduga faktor rasa cemas dan tegang saat wawancara ikut andil seperti yang dijelaskan Joni dalam penelitiannya. ${ }^{23}$ Akan tetapi, temuan ini sejalan dengan telaah Ekawarna pada lingkungan kerja yang menyebutkan bahwa lingkungan bising dapat menggangu memori dan konsentrasi kerja melalui rasa cemas. ${ }^{24}$

Hasil uji korelasi menunjukan hubungan (meskipun rendah) yang bermakna, yakni semakin parah derajat ketulian yang dialami 
pekerja secara pasti menyebabkan penurunan kemampuan kognitif mereka. Penelitian Park pada tikus menunjukkan hasil yang sama. Dijelaskan bahwa 1). Kehilangan pendengaran adalah salah satu faktor penyebab penurunan kognitif secara patologis, 2). Tikus dengan keterbatasan kognitif mempunyai $p$-tau dan tumpukan lipofuscin yang lebih banyak di hippocampus. ${ }^{11}$ Hasil yang serupa dijelaskan lebih lanjut oleh Conway tentang pentingnya suara untuk membangun kemampuan kognitif. Penelitian ini dilakukan dengan membandingkan kognitif anak tunarungu dan ketulian orang dewasa, dikemukakan bahwa keadaan tuli menyebabkan gangguan pengolahan fungsi kognitif di lobus temporal dan frontal otak. ${ }^{25}$ Namun, anak sejak lahir tunarungu dan orang dewasa adalah dua subjek yang tidak sama, sehingga dapat membuat rancu temuan ini. la menyarankan untuk mengekplorasi fungsi kortikal pada subjek hewan yang dibuat tuli. ${ }^{25}$

Penjelasan Tao terhadap hasil penelitian tersebut adalah karena timbulnya stres oksidatif akibat paparan bising yang berkepanjangan. ${ }^{26}$ Tao menambahkan hal yang serupa dengan temuan Park, yaitu terjadinya penurunan neurogenesis di hippocampus otak tikus yang berusia 0-2 bulan akibat bising yang dipaparkan sejak lahir. ${ }^{11,26}$

Shansky menjelaskan lebih lanjut bahwa bising memicu perubahan emosi (termasuk stres) yang selanjutnya menggangu kerja sistem saraf melalui jalur hipotalamuspituitari-adrenal (HPA) dan melepaskan neuromodulator seperti glukokortikoid, katekolamin, dan kelenjar gonad yang mengganggu fungsi prefrontal otak yang penting untuk menentukan cara berpikir, memutuskan sesuatu, perilaku (fungsi eksekutif), dan memori. Penelitian tersebut dilakukan pada primata dan tikus. ${ }^{27}$ Bedanya dengan penelitian ini adalah peneliti tidak mengeksplor lebih jauh terkait stres akibat bising pada pekerja, namun peneliti telah mengeklusi pekerja dengan depresi. Basner juga menyebutkan adanya korelasi antara bising dengan kejadian stres yang dilihat dari hormon stres yaitu hormon kortisol (termasuk katekolamin dan glucokortikoid) yang mengaktifkan amigdala di otak. ${ }^{1}$

Bising dapat meningkatkan tekanan darah. ${ }^{15,21}$ Bising juga mengakibatkan stres. ${ }^{24}$ Stres akibat bising juga dapat meningkatkan tekanan darah. ${ }^{1}$ Hasil penelitian Pandean menyebutkan bahwa tekanan darah yang tinggi juga menyebabkan penurunan fungsi kognitif. ${ }^{28}$ Pada penelitian ini faktor risiko tekanan darah telah diekslusi, tetapi angka kejadian gangguan kognitif masih sangat tinggi.

Hantaran suara berintensitas tinggi selain melalui udara, juga melalui tulang (bone conduction). Pada kasus ketulian akibat bising, gelombang suara dirambatkan melalui udara dan tulang sehingga menyebabkan kerusakan sel-sel rambut di dalam koklea. ${ }^{8}$ Pada kondisi terjadinya gangguan kognitif, peneliti menduga ada pengaruh hantaran suara melalui tulang kepala (cranium) terhadap rusaknya sel-sel otak yang juga berpengaruh menurunkan kemampuan kognitif pada pekerja. Akan tetapi belum ditemukan telaah ilmiah yang mendukung pendapat ini. Analisis sementara, peneliti berasumsi adanya resonansi suara berintensitas tinggi yang diterima tulang kepala dalam bentuk getaran dirambatkan kedalam otak dan mempengaruhi sel-sel otak secara langsung maupun tidak langsung. Disebut tidak langsung karena melalui turbulensi pada aliran darah otak. Tentunya asumsi ini perlu pembuktian lebih lanjut.

\section{Kesimpulan}

Terdapat hubungan antara derajat ketulian sensorineural akibat bising (NIHL) dengan kemampuan kognitif pada pekerja galangan kapal. Semakin berat derajat 
ketulian yang dialami subjek menyebabkan semakin rendahnya skor kemampuan kognitif.

\section{Saran}

Fokus utama Kesehatan dan Keselamatan Kerja (K3) terkait kejadian tuli sensorineural yang bersifat permanen pada pekerja yang terpapar bising adalah dengan selalu menggunakan alat pelindung telinga (ear plug/ear muff), sehingga bising tidak sampai menimbulkan dampak ketulian maupun penurunan kognitif yang akhirnya menggangu produktivitas perusahaan.

\section{Daftar Pustaka}

1. Basner M, Babisch W, Davis A, Brink M, Clark $C$, Janssen $S$, et al. Auditory and Non-Auditory Effects of Noise on Health. The Lancet. 2014;383(9925):1325-32.

2. Ryherd EE, Okcu S, Ackerman J, Zimring C, Persson K. Noise Pollution in Hospitals: Impacts on Staff. JCOM. 2012;19(11):491-500.

3. Umyati $A$, Yadi $Y H$, Anton. Seminar Nasional IENACO. In: Pengaruh Tingkat Kebisingan Terhadap Gangguan Pendengaran pada Karyawan PT.Citratama Persada Raya Sektor Blasting Painting. 2015. p. 155-62.

4. Christi WA, Suwondo A, Widjasena B, Keselamatan B, Masyarakat FK. Faktor Risiko Peningkatan Ambang Dengar Pekerja Pengelasan (Studi Observasional pada PT.X Kota Semarang Berdasarkan Umur dan Riwayat Penyakit. Jurnal Kesehatan Masyarakat. 2017;5(1):414-21.

5. Dewi YA, Agustian RA. Hearing Test Screening at One of the Textile Factory Workers in Bandung. Majalah Kedokteran Bandung. 2012;44(2):96100.

6. Menteri Tenaga Kerja. Keputusan Menteri Tenaga Kerja Nomor : KEP - 51
/ MEN / 1999 [Internet]. Indonesia; 1999 p. 1-9. Available from: https://qhseconbloc.files.wordpress.com/ 2011/07/1300758802kepmenakerno51th 1999ttgambangbatasfaktorfisikaditempat kerja.pd\#page=1\&zoom=auto,-107,842

7. Alwi AF, Basuki M, Fariya S. Penilaian Risiko K3L pada Pekerjaan Reparasi Kapal di PT.Dok dan Perkapalan Surabaya (persero). In: Seminar Nasional Kelautan XII. 2017. p. 1-11.

8. Salawati L. Noise-Induced Hearing Loss. Jurnal Kedokteran Syiah Kuala. 2013;13(1):45-9. Available from: http://www.jurnal.unsyiah.ac.id/JKS/articl e/view/2744

9. Alexopoulos EC, Tsouvaltzidou T. Hearing Loss in Shipyard Employees. Indian Journalof Occupationaland Enviromental Medicine. 2015;19(1):148. Available from: 10.4103/00195278.157000

10. Lumonang NP, Moningka M, Danes VR. Hubungan bising dan Fungsi Pendengaran pada Teknisi Mesin Kapal yang Bersandar di Pelabuhan Bitung. Jurnal e-Biomedik. 2015;3(3):728-32.

11. Park SY, Kim MJ, Kim HL, Kim DK, Yoe SW, Park SN. Cognitive Decline and Increased Hippocampal p-tau Expression in Mice with Hearing Loss. Behavioral Brain Research. 2018;342(April):19-26. Available from: http://dx.doi.org/10.1016/j.bbr.2018.01.0 03

12. Lindqvist $E$, Vestman $R$, Herrnstein RJ, Bowles S, Heckman JJ, Stixrud J. The Labor Market Returns to Cognitive and Noncognitive Ability: Evidence from the Swedish Enlistmen. American Economics Journal: Applied Economics. 2011;3(January):101-28.

13. Rahmasari L. Pengaruh Kecerdasan Intelektual, Kecerdasan Emosi dan Kecerdasan Spiritual Terhadap Kinerja Karyawan. Majalah IImiah Informatika. 
2012;3(1):1-20.

14. Rambe AS, Fitri Fl. Correlation between the Montreal Cognitive AssessmentIndonesian Version (Moca-INA) and the Mini-Mental State Examination (MMSE) in Elderly. Journalof Medical Sciences. 2017;5(7):915-9.

15. Harianto $E$, Pratomo H. Noise Exposure and Hypertension among Harbor Worker. KesMas: National Public Health Journal. 2013;8(5):215-20.

16. Jumali, Sumadi, Andriani $S$, Subhi $M$, Suprijanto D, Handayani WD, et al. Prevalence and Risk Factors Noise Induced Hearing Loss on the Ferry Machine Operator. Jurnal Kesehatan Masyarakat Nasional. 2013;7(12):54550.

17. Kuemba LS. Buruh Bagasi Kapal di Pelabuhan Kota Bitung. Jurnal Holistik. 2012; V(2):1-11.

18. Rambe AYM. Gangguan Pendengaran Akibat Bising. Jurnal Kedokteran Universitas Sumatra Utara. 2013;5(7):111.

19. Sabia S, Elbaz A, Dugravot A, Head E, Shipley M, Johnson $\mathrm{GH}$, et al. Impact of Smoking on Cognitive Decline in Early Old Age. Arch Gen Psychiatry. 2012;69(6):627-35.

20. Psaltopoulou T, Kyrozis A, Stathopoulos P, Trichopoulos D, Vassilopoulos D, Trichopoulou A. Diet, Physical Activity and Cognitive Impairment Among Elders: the EPIC -Greece Cohort (European Prospective Investigation into Cancer and Nutrition). Public Health Nutrition. 2008;11(10):1054-62.

21. Mani A, Mullainathan S, Shafir E, Zhao J. Poverty Impedes Cognitive Function.
Sciences Journal. 2013;341(6149):97680.

22. Diamond A. Executive Functions. Annual Review of Psychology. 2013;63(January):135-68.

23. Joni DAAW, Dharmayanti PAP. Pengaruh Anxiety dalam Speaking Activities. Jurnal Bakti Saraswati. 2016;5(2):122-32.

24. Ekawarna, Sofyan H. Pengaruh Kondisi Kerja Fisik, Partisipasi dalam Pengambilan Keputusan dan Kecemasan Terhadap Stress Pekerjaan Guru Sekolah Negeri di Kota Jambi. Jurnal Penelitian Universitas Jambi Seri Humaniora. 2010;12(1):25-35.

25. Conway CM, Pisoni DB, Kronenberger WG. The Importance of Sound for Cognitive Sequencing Abilities - The Auditory Scaffolding Hypothesis. SAGE Journal. 2009;18(5):275-80.

26. Tao S, Liu L, Shi L, Li X, Shen $P$, Xun $Q$, et al. Spatial Learning and Memory Deficits in Young Adult Mice Exposed to a Brief Intense Noise at Postnatal Age. Journalof Otology.2015;10(1):21-8. Availablefrom:

http://dx.doi.org/10.1016/j.joto.2015.07.0 01

27. Shansky RM, Lipps J. Stress Induced Cognitive Dysfunction: HormoneNeurotransmitter Interactions in The Prefrontal Cortex. Frontiers in Human Neurosciences. 2013;7(April):1-6.

28. Pandean GV, Surachmanto EE. Hubungan Hipertensi dengan Fungsi Kognitif di Poliklinik SMF IImu Penyakit Dalam RSUP Prof. Dr. R. D. Kandou Manado. Jurnal e-Clinic. 2016;4(1):1-6. 